\title{
The Victory of the Proletariat is Inevitable: The Millenarian Nature of Marxism
}

David T. Byrne

\begin{abstract}
This essay shows how Marxism, despite its atheist pretensions, was influenced by Scripture, particularly the Millenarian concept presented in the Book of Revelation. Marx's metaphysics described the world as a titanic struggle between the bourgeoisie and the proletariat. He predicts this struggle between good and evil will end in the triumph of the righteous, leading to future paradise when humanity returns to its pristine state. Marx contended it was his study of history and ultimately his discovery of the universal laws of economics that allowed him to predict the course of humanity, but I argue Marx's real source is not history or science, but Scripture. Before demonstrating Marx's Millenarianism, this essay begins with an overview of the idea and describes how the concept was popular among German intellectuals in Nineteenth Century.
\end{abstract}

Key words: Marx, Marxism, Millenarianism, scriptures

\begin{abstract}
It is, therefore, the task of history, once the other-world of truth has vanished, to establish the truth of this world. It is the immediate task of philosophy, which is in the service of history, to unmask self-estrangement in its unholy forms once the holy form of buman self-estrangement has been unmasked. Thus, the criticism of Heaven turns into the criticism of Earth, the criticism of religion into the criticism of law, and the criticism of theology into the criticism of politics. - K. Marx ${ }^{1}$
\end{abstract}

R. G. Collingwood contends, 'Any history written on Christian principles will be of necessity universal, providential, apocalyptic and by the materialist and universal laws of history, Marx's sequential notion of history climaxes with the confrontation between the bourgeoisie and proletariat. This recognition that the atheist Marx's thinking resembled

${ }^{1}$ Karl Marx, Contribution to the Critique of Hegel's Philosophy of Right, cited in The MarxEngels Reader, edited by Robert Tucker (New York: Princeton University Press, 1978), 54.

${ }^{2}$ R.G. Collingwood, The Idea of History (Oxford: Oxford University Press, 1946), 49.

(c) 2011 David T. Byrne

http://www.kritike.org/journal/issue 10/byrne december2011.pdf ISSN 1908-7330 
traditional religious notions is not news. ${ }^{3}$ With its Manichean view of the world, its belief in a return to paradise for humanity, its prophets who spread the good word and its sacred collection of texts, Marxism shares distinctive features with major religions. I do not intend to reinvent the wheel by interpreting Marxism as eschatology. My goal is more narrow and specific. I want to show how Marx was influenced by a particular theological notion, millenarianism. This allows us to understand Marx's prophesy without having to rely on its seemingly faulty "scientific" nature.

Specialists agree that the Book of Revelation from which the millenarian concept largely (although not completely) arises dates from the second half of the first century when Christianity was in its infancy and struggling against the Roman yoke, so Revelation gave Christians reason for hope and optimism, even in the times of deepest despair, because it promised victory for the righteous after intense conflict. It is the most sequential book in the Bible. Stages are not only implicit in millenarian thought -- clearly, this is not an age of heaven on earth -- they are explicit throughout the book. Most chapters in the Book of Revelations begin with the word 'then,' suggesting that the historical development occurs in distinct periods. Each pre-ordained event leads to another pre-ordained event:

Then I saw a beast come out of the sea with ten horns and seven heads...Then I saw another beast come out of the earth; it had two horns like a lamb's but spoke like a dragon...then I looked and there was a lamb standing on Mt. Zion and with him one hundred and forty-four thousand who had his and his father's name written on their foreheads...Then I saw another angel flying high overhead... Then I looked and there was a white cloud, and sitting on the cloud one who looked like the son of man with a gold crown on his head and a sharp sickle in his hand...Then I saw in heaven another sign, great and awe-inspiring: seven angels with seven last plagues, for through them God's fury is accomplished. ${ }^{4}$

The arrival of the Millennium follows a period of titanic struggle between good and evil which occurs in clearly delineated historical events or stages, meaning there is a laundry list of historical events which must be completed before the New Ages arrives. Contrary to popular assumptions, the Millennium is not a final end, but rather a one-thousand year respite. After the thousand years, Satan is released from the bottomless pit. He will gather the

${ }^{3}$ For more extensive discussion of Marxism's relationship with religion, see Catherine R. Harris, Karl Marx: Socialism as Secular Theology (St. Louis, Mo: Warren H. Green, 1988); or Giulio Girardi, Marxism \& Christianity, trans. by Kevin Traynor (New York: The Macmillan Co., 1968); or Robert G. Wesson, Why Marxism? (New York: Basic Books, 1976).

${ }^{4}$ Rev. 13-15 
peoples of the world for one more battle before finally being defeated during the Apocalypse, inaugurating a final era in history:

Then I saw a new heaven and a new earth. The former heaven and the former earth had passed away, and the sea was no more. I also saw the holy city, a new Jerusalem, coming down out of heaven from God, prepared as a bride adorned for her husband. I heard a loud voice from the throne saying, 'Behold, God's dwelling is with the human race. He will dwell with them and they will be his people and God himself will always be with them [as their God]. He will wipe every tear from their eyes, and there shall be no more death or mourning, wailing or pain, [for] the old order has disappeared. ${ }^{5}$

Despite the sinful nature of man and the wretched nature of this world, Christians still have reason to be optimistic about the future. Pain and misery disappear as man returns to his pristine state. Struggle and conflict yield progress and paradise. This is the end of history.

\section{Millenarianism in Nineteenth Century Germany}

German intellectuals genuinely believed that the Kingdom of God was imminent. ${ }^{6}$ The French Revolution seemed to be the apocalyptic event that would usher in a new and better world, but its devolution into terror, war and horror meant it could no longer be seen as an apocalyptic event in which the French radicals were on the side of light. In Germany particularly, Napoleon became the anti-Christ who the Germans must destroy in to fulfill millenarian prophecy. Only by defeating the French emperor and revolting against his oppression can Germany achieve its national destiny, marking a new era in history. Deeply influenced by these events, G.W.F. Hegel's philosophy interprets history as struggle, progress and ultimately, resolution. His biographers still debate his precise relationship with religion, but one can fairly say that although he rejected some central Christian premises, he was by no means a secular philosopher. He wrote to Fredrich Schelling, "May the Kingdom of God come and our hands not remain idle."7 No longer could humanity wait for the millennium; creating a new world requires human activity. The Hegelian Idealist dialect, in fact, rejects the materialism of the French Enlightenment while continuing the millenarian tradition of conflict and progress: Hegel stressed ideas, specifically the conflict between ideas, as a means for progress. The history of the world is a struggle between thesis and

${ }^{5}$ Rev. 21:1-4.

${ }^{6}$ See Nicholas Lobkowicz, Theory and Practice (South Bend, IN: Notre Dame Press, 1967) for more information on German millenarianism.

${ }^{7}$ Ibid., 160 
antithesis. Hegel's philosophy of history includes the Oriental, Greek, Roman and Germanic stages, so in essence, his dialectical method fuses Kant's Idealist and dualist metaphysics with Biblical notions of history, stages and prophecy. The Bible provided Hegel with a way to explain causation while integrating periodized history since history is only the battle between ideas. Hegel's dialectal philosophy combined the notion of struggle with a periodical concept of history that concludes with mind or spirit achieving freedom. Hegel proclaims an "end of history." Finally, it should be noted that thesis and antithesis are not necessarily as distinct as they may seem to be since thesis ultimately begets antithesis; the master creates the slave. Of course, Satan is nothing more than a fallen angel. He has not always been distinct, rather he emerged from God and heaven.

\section{Millenarianism in Marx}

Does Marx turns Hegel on his head, or more precisely, does he turn Biblical prophecy on its head? For Marx and his successors, the dialectical process -- the key to understanding reality -- is simply a life-and-death struggle, not between immaterial angels and demons, or between thesis and antithesis, but between classes. Hegel's dialectic asserts two contrasting concepts vying for supremacy, yet Marx asserts the inherent darkness and light of these concepts, or classes, so Marx turns Hegel's dialectic into a staunch Manichean philosophy, only deepening his debt to theology. Marx's prediction of violent political cataclysm is more in accord with Biblical prophecy than Hegel who in light of the French Revolution refrained from predicting earthly Armageddon. Marx was bolder. A generation removed from 1793-1815, Marx had no firsthand experience with the political upheavals of that era, allowing him to more freely preach violence, destruction and revolution to the modern world. Revolutionary political ideas distinguish Young Hegelians like Marx because in contrast to their Idealist master, the Young Hegelians not only treat history materialistically, they view drew political consequences from Hegel's thought.

Although Das Capital is Marx's magnus opus, the Communist Manifesto presents the clearest sketch of his philosophy of history. Written in the midst of the 1848 revolutions as chaos and violence envelope Europe in 1848, Marx predicts the dawning of the New Age, but only after good and evil confront each other. The history of the world is the history of two classes in conflict:

The history of all hitherto existing society is the history of class struggles. Freeman and slave, patrician and plebeian, lord and serf, guild-master and journeyman, in a word, oppressor and oppressed, stood in constant opposition to one another, carried on an uninterrupted, now hidden, now open fight, a fight that each time ended, either in a 


\section{BYRNE}

revolutionary reconstitution of society at large, or in the common ruin of the contending classes. ${ }^{8}$

Every era, every epoch is defined by these inherently antagonist, dueling forces. All history can be reduced to a battle of good versus evil, and there can only be one winner. Thus far, all history has been the victory of the ruling or oppressing classes. Like the fall of man, sin and misery characterize the past and present world:

Within the capitalist system all methods for raising the social productiveness of labour are brought about at the cost of the individual labourer; all means for the development of production transform themselves into the means of domination over and exploitation of, the producers; they mutilate the labourer into a fragment of a man, degrade him to the level of an appendage of the machine, destroy every remnant of charm in his work and turn it into a hated toil..."9

Whether it be the ancient, classical, feudal or modern epoch, evil prevails. The bourgeoisie, argues Marx, has created a world where 'naked, shameless, direct, brutal exploitation' reigns. ${ }^{10}$ Marx continues, 'Not only are they [the workers] the slaves of the bourgeoisie class, and of the bourgeoisie state, they are daily and hourly enslaved by the machine, by the over-looker, and above all, by the individual bourgeois manufacturer himself...'11 The material machine and capitalist becomes the instrument of exploitation, oppression and slavery; the bourgeoisie replaces Satan and his minions who previously caused all sin and misery in the Middle Ages.

Yet there is reason for hope and optimism because the capitalism system is inherently self-destructive. Believing themselves to be strong, the ruling classes are fundamentally weak. Latent contradictions will ultimately bring down the entire system. Competition between capitalists leads to the creation of monopolies that dominate the market, pushing the less successful capitalist to the rank of worker. As their numbers swell, class consciousness emerges. But the naïve capitalist works the proletariat even harder which only leads to more worker misery, and even more significantly, depressed wages. Then demand for products drops since wealth has become so concentrated in the hands of a tiny few. This leads to the crisis of over-production which Marx describes in apocalyptic terms:

${ }^{8}$ Karl Marx, 'The Communist Manifesto,' in The Marx-Engels Reader, ed. by Robert Tucker (New York: Norton \& Co, 1978) 473-474.

${ }^{9}$ Ibid., 479.

${ }^{10}$ Ibid., 475.

${ }^{11}$ Ibid., 479. 
In these crises there breaks there breaks out an epidemic that, in all earlier epics, would have seemed an absurdity the epidemic of over-production. Society suddenly finds itself put back into a state of momentary barbarism; it appears as if famine, a universal war of devastation had cut had cut off the supply of every means of substance; industry and commerce seem to be destroyed. ${ }^{12}$

Unemployment reaches epidemic proportions. Riots and violence grow worse. The capitalist, fully consumed with profits, fails to recognize that his bourgeoisie world is crumbling, and that he has forged the weapons that will destroy him. In his quest to crush everyone and everything in search of more capital, those who control the modes of production have merely driven the rest of society to abject poverty. Monopolies increase as large businesses take over small businesses, but since there is virtually no one left to buy their products, the crisis of over-production ensues. Then they dump their excess products on lesser developed nations, fostering industry and capitalism in these places. This leads to wars and more violence among capitalists and capitalist nations before the system's final disintegration. This collapse of the capitalism is highly periodized:

The proletariat goes through various stages of development. With its birth begins its struggle with the bourgeoisie. At first the contest is carried on by individual labourers, then by the workpeople of a factory, then by the operative of one trade, in one locality, against the individual bourgeois who directly exploits them. They direct their attacks not against the bourgeois conditions of production, but against the instruments of production themselves; they destroy imported wares that compete with their labour, they smash to pieces machinery, they set factories ablaze, they seek to restore by force the vanished status of the workman of the Middle Age. ${ }^{13}$

After these stages of development, the proletariat is ready to seize power:

Finally, in times when the class struggle nears the decisive hour, the progress of dissolution going on within the ruling class, in fact within the whole range of old society, assumes such a violent, glaring character, that a small section of the ruling class cuts itself adrift, and joins the 
revolutionary class, the class that holds the future in its hands. ${ }^{14}$

Or as Marx writes in the preface to the Critique of Political Economy:

At a certain stage of development, the material productive forces of society come into conflict with the existing relations of production or -- this merely expresses the same thing in legal terms -- with the property relations within the framework of which they have operated hitherto. From forms of development of the productive forces, these relations turn into their fetters. Then begins an era of social revolution. ${ }^{15}$

Following intense conflict and revolution, capitalism is swept away as the worker crushes the capitalist order, takes control of the modes of production and ushers in a new era in human history called socialism. The future belongs to the oppressed proletariat. The meek will inherit the earth.

Yet there is still work to be done. The defeat of the bourgeoisie and the advent of socialism does not mark an end of history, but rather marks a new stage in history, specifically the socialist stage when vestiges of the old world fade away before the glorious new age of communism arrives. In practice, this means new ways of thinking, working and living. The socialist stage lays the social and intellectual groundwork for the final glorious phase of human history. It prepares humanity for the end of history, the last stage of human society, communism. The communist world bears no resemblance to the sin-ridden capitalist world because it is void of private property. It creates true human freedom as the two disparate worlds -- one which until now is merely an Ideal realm-become united:

Communism as the positive transcendence of private property as buman self-estrangement, and therefore as the real appropriation of the buman essence by and for man; communism therefore as the complete return of man to himself as a social (i.e., human) being - a return accomplished consciously and embracing the entire wealth of previous development. This communism, as fully developed naturalism, equals humanism, and as fully developed humanism equals naturalism; it is the genuine resolution of the conflict between man and nature and between man and man - the true resolution of the strife between existence and essence, between objectification

${ }^{14}$ Ibid., 481.

15 Karl Marx, Preface to A Contribution to the Critique of Political Economy (Moscow: Progess Publishers, 1977). 
and self-confirmation, between freedom and necessity, between the individual and the species. Communism is the riddle of history solved, and it knows itself to be this solution. ${ }^{16}$

Communism is a return to the initial state of man, before his association with classes, private property and misery. Paradise lost becomes paradise regained: "In place of the old bourgeois society, with its classes and class antagonism, we shall have an association, in which the free development of each is the condition for the free development of all."17 True freedom and happiness arrive not when an immaterial God's Kingdom comes to Earth, but rather when all class distinctions vanish. S

Using Biblical prophecy to understand Marxism explains one of Marx's most famous paradoxes: if the victory of the proletariat is predetermined by history, why must revolutionaries -- including Marx himself - so vigorously promote socialism? Marx's universal law of economics seemingly proves that societies evolve through stages of development on their own, irrespective of human consciousness and activity, just as Medieval Man helplessly awaited the dawning of a New Age. However, although Marxism is metaphysically based on religious tradition, politically, Marx is a product of the modern era, a time when human activity supercedes God's will. The modern Marx is simply applying ancient and medieval concepts to his world, creating tension because the two worlds are not completely reconcilable. The Renaissance marks the beginning of liberation from religious concepts by stressing human significance, agency and freedom in the world. Whereas God dominated medieval history, human protagonists dominate modern history. Creating a world where human beings have no agency runs counter to modern thinking. Metaphysically, Marx comes from a historical era where events are explained by collisions between angels and demons, but politically, Marxism is a modern work, when human beings orchestrate historical events

\section{Conclusion}

Contrary to what Marx believed, there are never any complete breaks in history. The decline of religion and the rise of science among intellectuals in the eighteenth century did not mark an end to the questions that have plagued humanity for several thousand years, such as why is there pain and misery in the world, or how do we make it better? Marx's explanations for these questions and his prophecies are usually attributed to his 'discovery' of the materialistic laws of history; by observing past ages in history, Marx gained insight into the universal laws of economics and class struggle, allowing him to explain misery and predict the pristine future of society and humankind. He Reader, 84.

${ }^{16}$ Karl Marx, 'Economic and Philosophical Manuscripts of 1844,' in The Marx-Engels

${ }^{17}$ Karl Marx, 'The Communist Manifesto,' in The Marx-Engels Reader, 491. 
genuinely believed that he, like Newton, had discovered universal, scientific laws that allowed his disciples the ability to accurately understand earthly events and even make predictions about the future, just as Newtonian mechanics allowed for predictions about earthly and heavenly bodies. ${ }^{18} \mathrm{I}$ have tried to show that Biblical prophecy played an equally important role in Marx's thinking about the past, present and future. Marx does not overthrow traditionally patterns of thinking. He merely uses more modern (specifically scientific) nomenclature. The Book of Revelation and its millenarianism provide Marx with a method that integrates history, struggle and ultimately the triumph of good over evil.

Department of History, Loyola Marymount University, United States of America

\section{References}

Collingwood, R.G., The Idea of History (Oxford: Oxford University Press, 1946).

Girardi, Giulio, Marxism \& Christianity, trans. by Kevin Traynor (New York: The Macmillan Co., 1968).

Harris, Catherine R., Karl Marx: Socialism as Secular Theology (St. Louis, Mo: Warren H. Green, 1988).

Lobkowicz, Nicholas, Theory and Practice (South Bend, IN: Notre Dame Press, 1967).

'The Communist Manifesto,' in The Marx-Engels Reader, ed. by Robert Tucker (New York: Norton \& Co, 1978).

, Contribution to the Critique of Hegel's Philosophy of Right, cited in The Marx-Engels Reader, edited by Robert Tucker (New York: Princeton University Press, 1978).

, A Contribution to the Critique of Political Economy (Moscow: Progess Publishers, 1977).

Puledda, Salvatore, On Being Human (San Diego: Latitude Press, 1997).

Wesson, Robert G., Why Marxism? (New York: Basic Books, 1976).

18 For a humanist interpretation of Marxism, see Salvatore Puledda, On Being Human (San Diego: Latitude Press, 1997). 